\title{
DIRECTED-PROJECT BASED LEARNING AS LANGUAGE LEARNING MODEL: DESIGNING, DEVELOPING AND FIELD TESTING
}

\author{
Tri Pratiwi ${ }^{1}$ \\ Sufyarma Marsidin² \\ Hermawati Syarif 3 \\ Yahya 4 \\ ${ }^{1}$ Muhammadiyah University of West Sumatera \& \\ Science of Education Program, State University of Padang (UNP) \\ Email: triepratiwi28@yahoo.com \\ 2,3,4 State University of Padang (UNP) \\ ${ }^{2}$ sufyarma.marsidin_mc@yahoo.com \\ 3hermawati_sy@yahoo.com \\ 4endriaqra@gmail.com
}

\begin{abstract}
The aim of the present study is developing English learning model to increase students' language skills in English subject for VIII graders of SMP $N 1$ Uram Jaya through Directed-Project Based Learning (DPjBL) implementation. This study is designed in Research and Development $(R \&$ $D)$ using ADDIE model development. The researcher collected the data through the test, questionnaire, observation, and interview which were then analyzed qualitatively and quantitatively. The study revealed that DirectedProject Based Learning (DPjBL) implementation is significantly able to be one learning model allowing to increase student's language skills.
\end{abstract}

Keywords: Learning model, Directed-Project Based Learning (DPjBL), language skills

\section{INTRODUCTION}

There are four language skills in learning English, including listening, speaking, reading and writing skills (Tarigan, 2008). These four aspects cannot be separated one another since they are mutually sustaining, and mutually supportive. Similarly, that is in the English learning case of Junior High School (SMP) students. English learning in junior high school should combine the four language skills. Besides, the importance of integrating the four language skills in one learning activity is because English in Indonesia serves as a foreign language. It also makes students learn English thoroughly or wholly and not separated so that learners will be familiar with some 
Pratiwi, Marsidin, Syarif, Yahya, Directed - Project Based Learning (DPjBL) ...

activities of presentation, discussion, critical thinking, problem-solving and collaboration by using proper and correct language.

However, it is indisputable that the less optimal outcomes of English learning are a matter that frequently arises from a learning process. Based on data obtained from The Head of Primary and Secondary Education of Lebong Regency about the spread of National Examination (UNAS) scores in Bengkulu Province for academic year 2015/2016, the researcher found that Lebong Regency was in the lowest rank for all subjects tested in the national examination with the average value of 170. 28 even English score of Lebong District was the worst value compared to other areas that are 41. 19 declining from 41.87 for the previous year score. The standard minimum of learning mastery is 6.00 which means that more than 59\% from 1.684 students did not reach the minimum score. This case had already happened from 20015 to 2017 to which National Exam score of Lebong District was always in the lowest rank. English score of SMP N 1 Uram Jaya students was the worst too where the score was 36. 37 declining from 38. 75 for the previous year score.

Due to the results which are not in line with expectation mentioned above, the researcher is interested in applying one learning model offered in the 2013 curriculum that is project-based learning models (PjBL). Projectbased learning model (PJBL) is a learning method using project/activity as one learning medium. This learning model places learners as the center of learning activity in which students engage in exploration, assessment, interpretation, synthesis, and information to produce different forms of learning outcomes. The steps of $\mathrm{PjBL}$ is getting an idea, designing the Project, tuning the project (preparing project), doing the project, and exhibiting the project (presentation or project exhibition) (Patton, 2012).

There is some researchs showed the success of $\mathrm{PjBL}$ implementation, one of the research conducted by Lindawati (2013). Her study was aimed to increase creativity in IPS learning through Project Based Learning model. The results showed that the model of Project Based Learning could improve the creativity of the students. Another research was conducted by Lestari. In the publication of her research results shows that the implementation of learning model of Project Based Learning can improve the learning outcomes of 


\section{EduLite}

Journal of English Education, Literature, and Culture

students of class XI of Multimedia. The increasing of student learning outcomes seen in each of average percentage of learning outcomes of $68.86 \%$ increased to $83.32 \%$ (Lestari, 2015).

The researcher implemented the learning model of Project Based Learning as one as alternative solution to solve problems faced by teachers and students in the learning process. Project Based Learning is expected to be able to encourage students to be active, creative, innovative, productive and able to collaborate well in every learning process activities to improve student learning achievement and ability to speak in English both oral and written fluently, precisely and quickly understood.

From the results of field observations and interviews, for junior high school (SMP) the learning model of Project Based Learning (PjBL) is a bit hard to implement since it requires independence and high discipline in running PjBL learning model activity by the actual procedure. Due to the condition of junior high schools (SMP) in Lebong District and the ability of students who are still far from independent attitude and discipline then the learning must involve in guidance or direction from the teacher.

This case is due to out of 24 junior high schools in Lebong District, only two schools namely SMP N 1 North Lebong and SMP N 1 Lebong Tengah implementing 2013 Curriculum. The rest of them around 22 junior high schools still implement KTSP and in a trial stage of implementing 2013 Curriculum in the academic year of July - December 2016 which means that it has only been running for one semester. So it can be concluded that students are in adaptation stage of 2013 curriculum change (Head of Primary \& Secondary Education, 2016).

Based on the problems above, it is necessary to develop an exciting, impressive and meaningful concept of English learning. The development performed by the researcher is to design a Directed - Project Based Learning or here in after referred to as $\mathrm{DPjBL}$. The goal is that students can apply $\mathrm{PjBL}$ learning model activity while the teacher still directs them so that the function of teachers not only as a facilitator but also mentor who guides and directs students in every single learning activity. Research on the success of improving student achievement in the learning process with directional 
Pratiwi, Marsidin, Syarif, Yahya, Directed - Project Based Learning (DPjBL) ...

learning model has been proved (Lisna, 2014), which states that active learning method of directional learning model can have a positive effect on student learning motivation and improve student learning achievement significantly. The description of Directed-Project Based Learning, as follows;

Table 1. DPjBL Learning Stage

\begin{tabular}{|c|c|c|}
\hline NO & Learning Stage & Class Activity \\
\hline 1. & Modelling by The Teacher & $\begin{array}{l}\text { At this stage, the teacher will give an } \\
\text { explanation of theme, topic or object that } \\
\text { will be material for project design } \\
\text { activities, as well as provide samples of } \\
\text { products that will be done by students, so } \\
\text { that students can observe directly } \\
\text { samples of products they will do. }\end{array}$ \\
\hline 2. & Observation & $\begin{array}{l}\text { Teacher asks students to conduct } \\
\text { individual observations on the subject } \\
\text { matter. The teacher also asks students to } \\
\text { seek information on topics either through } \\
\text { the handbook or other media. }\end{array}$ \\
\hline 3. & $\begin{array}{l}\text { Get an Idea (Stated the } \\
\text { Problem) }\end{array}$ & $\begin{array}{l}\text { Learning begins with an essential } \\
\text { question that is a question that can give } \\
\text { assignments to students to perform an } \\
\text { activity. The topic taken must be relevant, } \\
\text { in line with the real-world reality and } \\
\text { begin with an in-depth investigation. } \\
\text { Teacher directs students with questions } \\
\text { until students understand the topic or } \\
\text { theme they will be working. }\end{array}$ \\
\hline 4. & $\begin{array}{l}\text { Choose the Alternative } \\
\text { Solution }\end{array}$ & $\begin{array}{l}\text { At this stage, it is to do collaborative } \\
\text { planning between teachers and students } \\
\text { so that students feel "owning" the project } \\
\text { which is planned. This plan contains } \\
\text { rules of the game, selection of supportive } \\
\text { activities in answering essential }\end{array}$ \\
\hline
\end{tabular}


questions, integrating various subjects that may be an alternative solution choice later.

\begin{tabular}{|c|c|c|}
\hline 5. & Design the Project & $\begin{array}{l}\text { At this stage, the collaboration between } \\
\text { teacher and students is made. The } \\
\text { teacher prepares materials and tools by } \\
\text { the theme of the project to be done. Then } \\
\text { students are asked to design the project } \\
\text { following tools and materials that have } \\
\text { been provided by the teacher. Collection } \\
\text { of information can be conducted through } \\
\text { books or digital media. Teacher and } \\
\text { students revise projects together, but } \\
\text { project decisions remain on students' } \\
\text { hand, teacher only directs students to } \\
\text { focus on the theme. }\end{array}$ \\
\hline 6. & Steps of Implementation & $\begin{array}{l}\text { At this stage, Teacher or students; (1) } \\
\text { make project completion timelines; (2) } \\
\text { make project completion deadlines; (3) } \\
\text { guides students to plan steps to take; (4) } \\
\text { guides students when they make } \\
\text { unrelated steps project, and (5) asks } \\
\text { students to make an explanation or } \\
\text { reason for the selection of the project. }\end{array}$ \\
\hline 7. & Reflection & $\begin{array}{l}\text { Reflection is done both individually and in } \\
\text { groups. At this stage, Teacher and } \\
\text { students develop discussions to improve } \\
\text { the performance which has been already } \\
\text { done in the design by which a new finding } \\
\text { is found to answer the essential question } \\
\text { posed. }\end{array}$ \\
\hline 8. & $\begin{array}{l}\text { Do the Project (Experiment } \\
\text { the Project) }\end{array}$ & $\begin{array}{l}\text { At this stage, students undertake or work } \\
\text { on projects that have been previously }\end{array}$ \\
\hline
\end{tabular}


Pratiwi, Marsidin, Syarif, Yahya, Directed - Project Based Learning (DPjBL) ...

designed, in groups. The teacher will observe student co-operation, in case of debate, the teacher will assess how students seek solutions. Supervision is done by the teacher as long as the student completes the project. Supervision can be done by facilitating students in each process and serve as a mentor for each student activity.

9. Exhibit The Project At this stage, students will present their (Presentation Result of the products made in the group to Project) reconstruct or build new knowledge to be intact for all learners.

10. Assessment Assessment is made to measure standard achievement, evaluate each student's progress, provide feedback on the level of student understanding that has been achieved, and help the teacher to develop future learning strategies. At the end of the learning process, the teacher will appreciate the product results that have been completed by the students. 


\section{EduLite}

Journal of English Education, Literature, and Culture

Directed - Project Based Learning is a development model which is used to bridge between conventional learning that has been rooted in every learning activity in the classroom and DPjBL learning. In this DPjBL learning model, students will not feel rigid because the learning method does not drastically change but step by step will make students autonomous in every learning activity in the classroom. Even this DPjBL learning model will prepare children mentally and skills if the school will implement the curriculum 2013 as a whole that requires students to be independent, disciplined and competitive.

\section{DISCUSSION}

This study is designed in Research and Development ( $R$ \& $D$ ) type. In this research the development model used is ADDIE. The concept of ADDIE model is Analysis, Design, Development, Implementation, and Evaluation (Robert Maribe Branch, 2009). The first step was Analysis. Before researcher started developing the learning model, the researcher had analyzed the current situation of the teachers, students and school. Started with series of questions to understand the current situation and to also understand what is the goal of the learning model itself. This influenced a huge amount of decisions later in the process.

Data collection used was questionnaire, interview, observation and also documentation. The second step was Design. A blue print or an outline of instructional strategies was created including learning content, activities, assessments, and media selection of the learning model. The third step was Development. the actual creation (production) of the learning model and learning materials based on the Design phase. In this phase involves some validators, the English material experts and media experts, it will be seen how valid the learning model that can be applied in the field.

The fourth step was Implementation. During implementation, the plan is put into action and a procedure for training the learner and teacher is developed. Materials are delivered or distributed to the student group. After delivery, the effectiveness of the training materials is evaluated. In finding out te effectiveness of learning model, the researccher used T-test. And the last step was Evaluation. This phase consists of (1) formative and (2) summative 
Pratiwi, Marsidin, Syarif, Yahya, Directed - Project Based Learning (DPjBL) ...

evaluation. Formative evaluation is present in each stage of the ADDIE process. Summative evaluation consists of tests designed for criterion-related referenced items and providing opportunities for feedback from the users. Revisions are made as necessary

This research was conducted at SMP N 1 Uram Jaya Lebong District academic year 2017/2018 for VIII graders in English subjects with the topic of the Descriptive texts, Invitation Card, and Greeting Card.

The researcher collected data through observation for need analysis, questionnaire of student's perception about $\mathrm{DPjBL}$ and questionnaire of practicality for books product, interview, and documentation which were then analyzed qualitatively by using (Miles and Huberman, 1992) interactive concepts that are data reduction, data display and conclusion (drawing/verifying). And test instrument for finding out the effectiveness of DPjBL and also students' English achievement which were then analyzed quantitatively by using T-test.

The results of preliminary analysis on the condition of English learning at this Junior High School showed that the current condition of learning either the teachers' condition or the school, curriculum, students, infrastructure condition and government policy especially in education still require further improvement, correction and special attention especially for English learning management related to the teachers' ability and necessary infrastructure facilities.

The process of DPjBL development model may include the initial design of the English learning model planning, then media, material and evaluation experts validate the initial product design. The product validation average result was 4.78 from the maximum value of 5.00, indicating that it was strongly valid, and can be used in the implementation stage.

Before conducting research, the teacher distributed the questionnaires on the students' perceptions feasibility test on PBL model to students and after research, the teacher provided questionnaires of students' perceptions feasibility test on the developed PBL model called DPjBL. The comparison of students' perception feasibility test results is given as follows. 


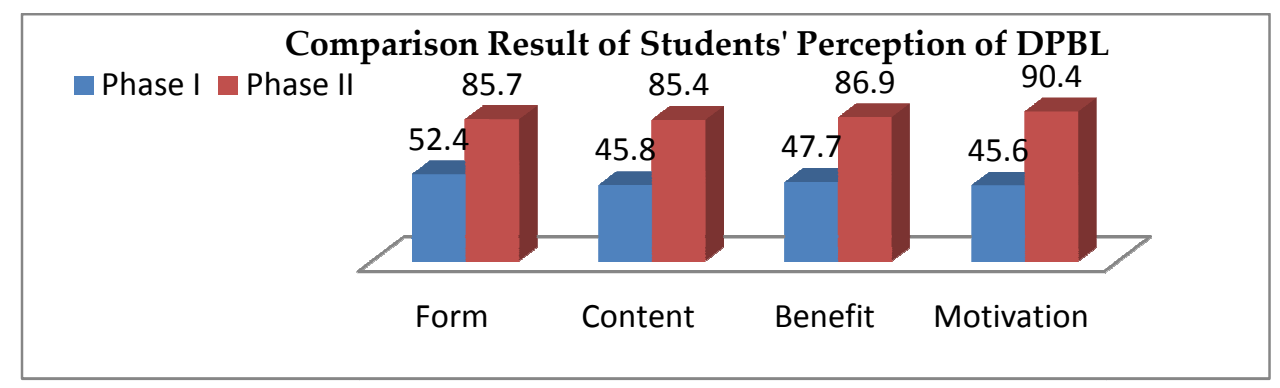

Figure 1. Comparison Result of Students' Perception of DPBL

The chart above showed that those students' perceptions on the developed model were significant in which the $85.7 \%$ of students agreed that the form of DPjBL model was very interesting; 85 . $4 \%$ of students stated that the content of the $\mathrm{DPjBL}$ model was awfully appropriate and effective for English learning; 86. 9\% of students also argued that this DPjBL model provided enormous benefits in the English learning process. Finally, around 90. $4 \%$ of students said that they had high motivate onto learn English using this DPjBL model.

The result of students' book product practicality was also fairly high at 4.85 or $97.0 \%$ of students approved the use of DPjBL book in English learning process. And the result of teacher's book product practicality was also high at 4. 67 or 93 . 3\% of teachers stated that teacher's book product was very effective in English learning process.

The last is the results of t-test calculation, suggesting that student's English learning outcomes increased significantly. The following chart presented the comparison between pre-test and post-test results as well as ttest results.

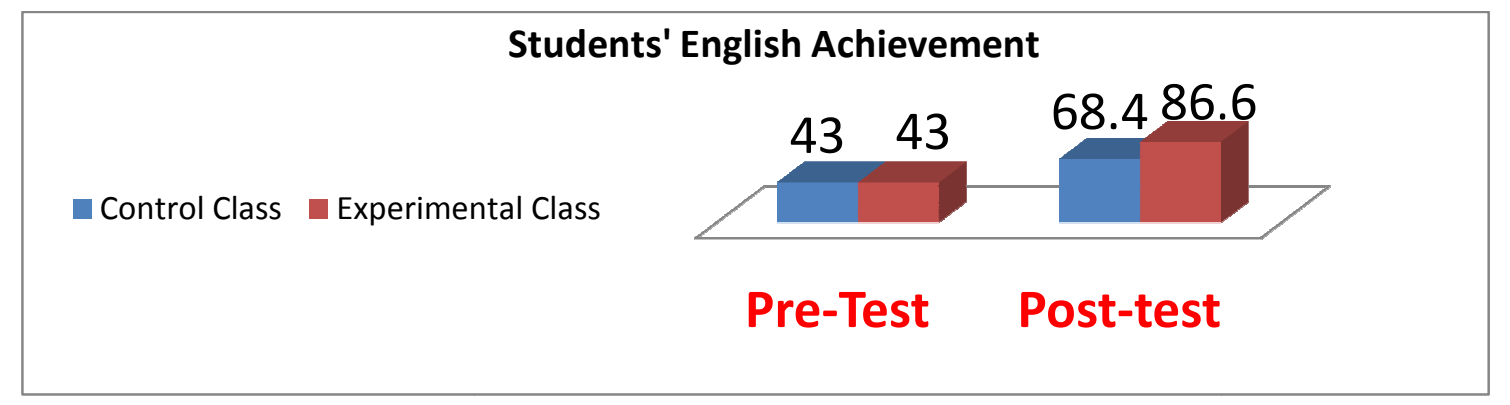

Figure 2. Students' English Achievement 
Pratiwi, Marsidin, Syarif, Yahya, Directed - Project Based Learning (DPjBL) ...

Table 2. The Results Description

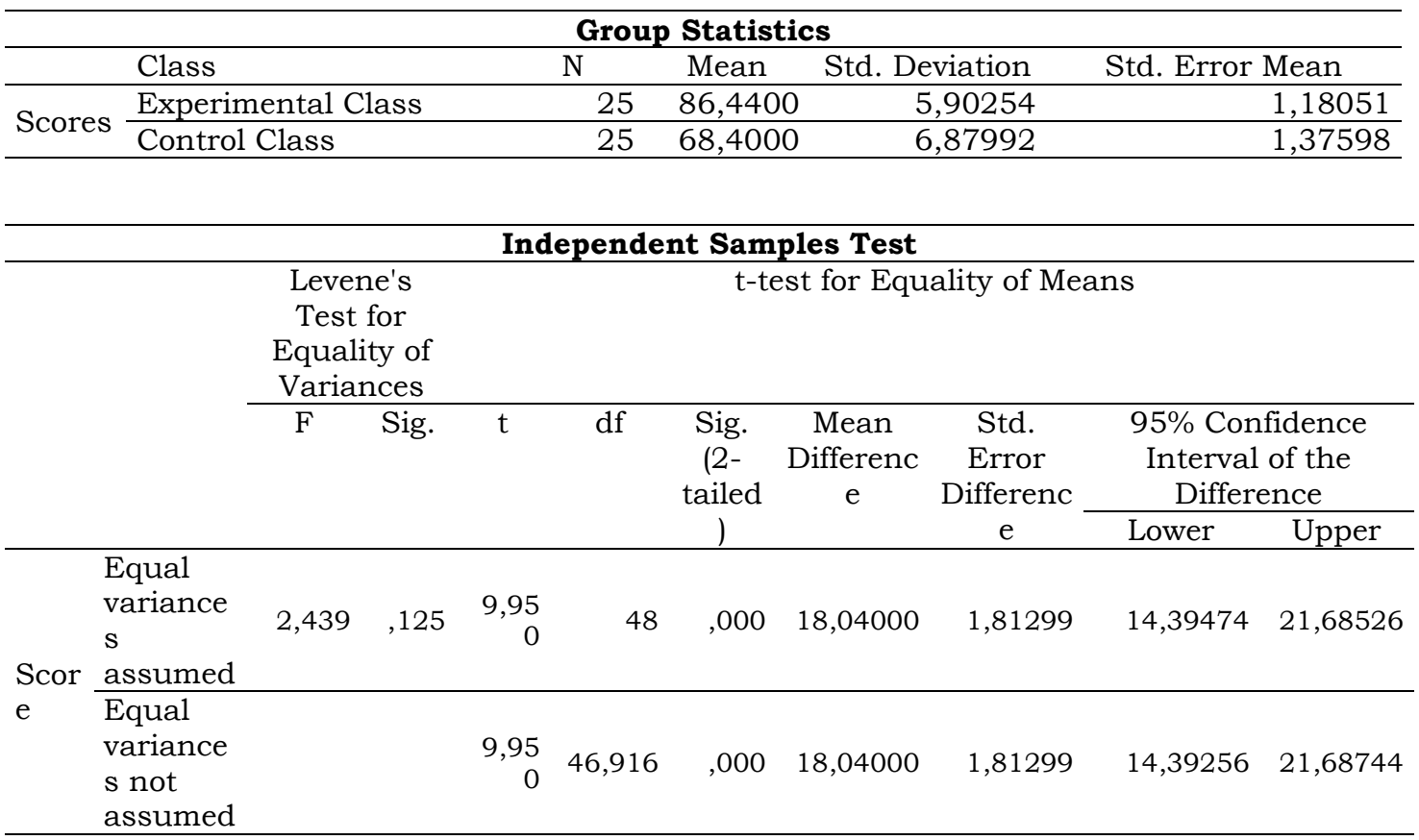

From the above table, the researcher found that the post-test difference between the control and experimental classes was 68.4 for the control class and 86.6 for the experimental class. The t-test above also demonstrated that the value of sig. (2-tailed) was $0.000<0.05$. In short, it concluded that the $\mathrm{DPjBL}$ model is more effective than conventional learning.

\section{CONCLUSION}

Based on research objectives and explanation of the results obtained in research on DPjBL model development, it can be concluded as follows; product of DPjBL model development is feasible to use in English learning at SMP Negeri 1 Uram Jaya. The evaluation results of English learning material experts, learning model designers, teacher assessment, and students' assessment proved that DPjBL model is effectively applied in English learning at SMP Negeri 1 Uram Jaya. This is known from the increase in evaluation results at the post-test stage.

From the results of questionnaire filled in, students generally agreed with DPjBL learning model. This learning model can increase the motivation to 
learn, grow self-esteem, courage to express opinions, and appropriate for the students' character.

\section{REFERENCES}

Borg, W.R \& Gall, M.D. (1983). Educational research, an introduction. New York: Longman Inc.

Branch, R.M. (2009). Instructional design: The ADDIE approach. New York: Springer Science \& Business Media, LLC.

Buck Institute of Education. (2016). Project-based Learning Web page. [Brochure]. CA: Author.

Cangara, H. (2007). Pengantar ilmu komunikasi. Jakarta: PT. Raja Grafindo Persada.

Lestari, T. (2015). Peningkatan hasil belajar kompetensi dasar menyajikan contoh-contoh ilustrasi dengan model pembelajaran project based learning dan metode pembelajaran demonstrasi bagi siswa kelas Xi multimedia SMK Muhammadiyah Wonosari. [Thesis]. Wonosari: Author

Lindawati. (2013). Penerapan model pembelajaran project based learning untuk meningkatkan kreativitas siswa MAN I Kebumen. (Radiasi. Vol.3.No.1). diunduh dari http:// download.portalgaruda.org/article.php?article $=97636 \& v a l=6$ 14. (Desember 2016, 20:02 WIB)

Lisna, J. (2014). Metode belajar aktif model pengajaran terarah dalam meningkatkan prestasi belajar siswa pada pelajaran IPS Kelas IV SDN105 Kota Utara Kota Gorontalo. [Thesis]. UNG. Gorontalo: Author

Miles, M.B. dan Huberman, A.M. (1992). Analisis data kualitatif. Jakarta. Universitas Indonesia Press

Patton, A. (2012). Work that matters: The teacher's guide to project-based learning. London: Paul Hamlyn Foundation.

Tarigan, H.G. (2008). Membaca sebagai suatu keterampilan berbahasa. Bandung: Angkasa. 